\title{
Development of turbidity index as field method to detect mixing of heated milk with raw milk
}

\author{
MRH Rakib', R Habib*², MN Hassan², MF I mam³, MN Hassan ${ }^{4}$ \\ ${ }^{1}$ Bangladesh Livestock Research Institute, Savar, Dhaka; ${ }^{2}$ Department of Dairy Science, Bangladesh \\ Agricultural University; ${ }^{3}$ Department of Agricultural Statistics, Bangladesh Agricultural University, Mymensingh \\ 2202; ${ }^{4}$ BRAC Dairy and Food Project, Gazipur, Dhaka, Bangladesh.
}

\begin{abstract}
The research was undertaken to determine the amounts of precipitate formed in the milk plasma due to mixing of different levels of heated milk with raw milk, and to establish a turbidity index, which will be helpful as a field method in detecting the extent of addition of heated milk. The tests were conducted on five different treatments namely, Milk sample A (100\% Heated milk), Milk sample B (75\% Heated milk + $25 \%$ Raw milk), Milk sample C (50\% Heated milk + 50\% Raw milk), Milk sample D (25\% Heated milk + $75 \%$ Raw milk) and Milk sample E (100\% Raw milk). Samples were examined by chemical analysis including fat content, protein content, dry matter content, ash content, $\mathrm{pH}$, acidity, turbidity test, and precipitation content of plasma. There was a highly significant difference $(p<0.001)$ in case of fat, protein and precipitate contents of plasma as affected by extent of addition of heated milk. A statistically significant difference $(p<0.05)$ was also found for ash content. On the other hand, no significant difference was found in case of dry matter content, $\mathrm{pH}$ and acidity of milk. A strong correlation $\left(R^{2}=0.819\right)$ was observed between the amount of precipitate and proportion of heated milk mixed with raw milk. A field method was devised on the basis of extent of turbidity, which was in fact amount of precipitate formed in the milk plasma as a function of extent of the addition of heated milk to raw milk.
\end{abstract}

Key words: Heated milk, turbidity index

Bangladesh Animal Husbandry Association. All rights reserved. Bang. J. Anim. Sci. 2014.43 (2): 123-127

\section{I ntroduction}

Raw milk of good hygienic quality is necessary to produce milk products of good quality and adequate shelf-life and to provide a safe, sound and wholesome food for the consumer. In principle farmer should supply the raw milk absolutely untreated and unadulterated. However, in our country and many developing countries, a large number of dairy farmers kept their milk by heating that they cannot sell on a given day, and mix them with freshly collected raw milk of the following day. It may reduce the quality of raw milk as well as pose problems during subsequent processing.

Boiling is the easiest method of increasing shelflife of milk at home. The nutritive value of the milk, namely some vitamins (heat sensitive vitamins) and proteins, is affected depending upon the type of boiling process. Boiling of milk destroys all microorganisms except the spore formers but it changes the nutritive value of milk, its flavors, palatability, and appearance may also create acute difficulties on further processing. Virtually all milk and milk products are processed by heat to some degree and stored for a period of time. Milk is a complex entity and contains many components that may be precursors of off-flavor chemicals (proteins, fat, lactose, etc.). Reactions occurring between milk components during the heating or storage of milk products result in offflavors.

Turbidity test of milk is applicable for the detection of this heated milk mixed with raw milk. It depends upon the denaturation of whey proteins, especially albumin, during boiling. Turbidity measures the "cloudiness" of water; more precisely, it measures the extent to which light is scattered and absorbed by suspended sediment and dissolved organic matter (Clesceri et al. 1998). From a technical standpoint, turbidity is a relative measurement of scattering versus a calibrated standard, usually a formazin suspension (Davies-Colley and Smith 2001). The milk sample is treated with ammonium sulphate, and then filtered to collect plasma, and then the 


\section{Turbidity index to detect mixing of heated and raw milk}

filtrate is heated to detect signs of turbidity due to presence of albumin. If milk has been boiled all albumins would have been coagulated and no turbidity will be seen. In contrast, untreated raw milk will show acute signs of turbidity. But, the presences of whey protein into plasma after filtration add its subsequent coagulation during boiling of the plasma for the turbidity test to give a positive result, which is an indication of the milk being raw. The amount of whey protein drained into plasma upon turbidity test should vary as a function of proportion of heated milk added.

If heated milk is mixed with raw milk, some portion of whey protein would inevitably be found in the plasma upon the turbidity test which might confused the person who tries to detect the science of heated milk. Because, presence of whey protein into plasma after filtration add its subsequent coagulation during boiling of the plasma for the turbidity test to give a positive result is an indication of the milk being raw. Hence an index should be developed to detect the amount of heated milk mixed with raw milk. Interestingly, farmers may mix small portions of heated milk with a larger portion of raw milk. So that consumers and milk processing industry can't identify this kind of treatment. In the aspect of Bangladesh, extensive research work is essential to establish a turbidity index to detect the small amount of heated milk mixed with raw milk. A small number of researches have been conducted on the turbidity test of milk, but none focused on the detection of extent of heated milk. For this reason the present work was undertaken to establish a turbidity index for the detection of extent of heated milk added to raw milk based on the amounts of precipitate formed due to mixing of different levels of heated milk to raw milk.

\section{Materials and Methods}

Whole milk was collected from Bangladesh Agricultural University Dairy Farm, Mymensingh during the period from July to October 2013. Five different types of experimental milk samples were prepared by adding heated milk to raw milk.

Treatment A: $100 \%$ heated milk

Treatment B: $75 \%$ heated milk $+25 \%$ raw milk Treatment C: $50 \%$ heated milk $+50 \%$ raw milk Treatment D: $25 \%$ heated milk $+75 \%$ raw milk Treatment E: $100 \%$ raw milk
From each of the treatment $20 \mathrm{ml}$ milk was taken in a test tube and $4 \mathrm{~g}$ ammonium sulphate was dissolved. The mix was filtered through filter paper. Five (5) $\mathrm{ml}$ of plasma was collected from each portion of the experimental milk samples. Upon heating at $80^{\circ} \mathrm{C}$ for 5 minutes, the plasmas were examined for the science of turbidity. The plasmas were than filtrate to separate the whey protein followed by drying of the proteins in a hot air oven for 5 hours at $106^{\circ} \mathrm{C}$ temperature. The weight of whey protein was then precisely measured and expressed as percentage of whey protein present in plasma. These coefficients were then used as index to detect the extent of heated milk added to raw milk.

Each of the samples was judged by a panel of expert judges for sensory evaluation. The panelists were selected from among the teachers and students of the Department of Dairy Science, Bangladesh Agricultural University, Mymensingh. The panelists were asked to evaluate on the basis of numerical score (Nelson and Trout 1948). Chemical analysis was done for each milk sample to detect dry matter content $(\mathrm{g} / \mathrm{Kg})$, fat content $(\mathrm{g} / \mathrm{Kg})$, protein content $(\mathrm{g} / \mathrm{Kg})$, ash content $(\mathrm{g} / \mathrm{Kg}), \mathrm{pH}$, titratable acidity $(\%)$, and precipitation content in plasma (\%). Acidity was determined by titrating with $0.1 \mathrm{~N} \mathrm{NaOH}$ solution (Aggarwala and Sharma 1961). pH was measured with the help of a pH meter-215 (Ciba Coming Diagnostics Ltd., Sundhury, Suffolk, England Co 106xD). Fat content was determined by the Babcock method following the procedure described by Aggarwala and Sharma (1961). Crude protein (CP), dry matter (DM), ash content of samples were determined by according to AOAC (2003).

Data collected were subjected to Analysis of Variance (ANOVA) in Completely Randomized Design (CRD) by using SPSS statistical package. The differences among treatment means were compared by Duncan's Multiple Range Test (DMRT) (Gomez and Gomez 1984). To find the relationship between \% precipitate and extent of addition of heated milk, correlation and regression analysis was performed.

\section{Results and Discussion}

Milk samples were tested for off flavor, especially the presence of cooked or burnt flavor. Only the 
fully boiled milk exhibited mild cooked flavor, whereas, all other samples including those mixed with boiled milk did not show any signs of cooked flavor (Table 1). There was no significant difference among the DM content of milk collected from different treatments (Table 1). The dry matter content of cow milk was found to be 112.3-142.6 g/ Kg (I mran et al. 2008; Enb et al. 2009; Mahboba and Zubeir 2007). The increase in dry matter content in heated milk might be due to evaporation of moisture as a result of heating (Walstra and Jenness 1984).

Table 1. Chemical parameters of raw milk, heated milk, and mixes of different proportions of raw and heated milks

\begin{tabular}{lccccc}
\hline Para- & \multicolumn{5}{c}{ Treatment (Mean \pm SD) } \\
\cline { 2 - 6 } meters & $\mathrm{A}$ & $\mathrm{B}$ & $\mathrm{C}$ & $\mathrm{D}$ & $\mathrm{E}$ \\
\hline DM (g/kg) & 184.0 & 165.7 & 152.2 & 151.7 & 128.1 \\
& \pm 18.1 & \pm 15.7 & \pm 2.9 & \pm 11.6 & \pm 7.8 \\
\hline \multirow{2}{*}{ Flavor (Score) } & $37.0^{\mathrm{c}}$ & $40.0^{\mathrm{b}}$ & $40.0^{\mathrm{b}}$ & $40.0^{\mathrm{b}}$ & $41.0^{\mathrm{a}}$ \\
& \pm 1.00 & \pm 1.00 & \pm 1.00 & \pm 1.00 & \pm 1.00 \\
\hline Fat (g/kg) & $55.2^{\mathrm{a}}$ & $54.2^{\mathrm{ab}}$ & $52.5^{\mathrm{bc}}$ & $51.2^{\mathrm{cd}}$ & $50.0^{\mathrm{d}}$ \\
& \pm 1.3 & \pm 0.6 & \pm 0.9 & \pm 1.0 & \pm 1.3 \\
\hline Protein & $34.2^{\mathrm{c}}$ & $34.8^{\mathrm{c}}$ & $36.0^{\mathrm{b}}$ & $36.7^{\mathrm{b}}$ & $38.0^{\mathrm{a}}$ \\
(g/kg) & \pm 0.6 & \pm 0.3 & \pm 0.9 & \pm 0.7 & \pm 0.5 \\
\hline Ash (g/kg) & $7.9^{\mathrm{a}}$ & $7.1^{\mathrm{ab}}$ & $7.2^{\mathrm{ab}}$ & $6.7^{\mathrm{b}}$ & $6.5^{\mathrm{b}}$ \\
& \pm 0.3 & \pm 0.6 & \pm 0.5 & \pm 0.5 & \pm 0.2 \\
\hline pH & 6.5 & 6.7 & 6.7 & 6.7 & 6.8 \\
& \pm 0.2 & \pm 0.1 & \pm 0.1 & \pm 0.1 & \pm 0.1 \\
\hline Acidity (\%) & 0.24 & 0.22 & 0.21 & 0.19 & 0.19 \\
& \pm 0.06 & \pm 0.04 & \pm 0.02 & \pm 0.02 & \pm 0.02 \\
\hline Precipitate & $3.2^{\mathrm{d}}$ & $3.4^{\mathrm{cd}}$ & $3.6^{\mathrm{bc}}$ & $3.5^{\mathrm{ab}}$ & $3.9^{\mathrm{a}}$ \\
(\%) $^{\text {(\%) }}$ & \pm 0.12 & \pm 0.13 & \pm 0.08 & \pm 0.08 & \pm 0.24 \\
\hline
\end{tabular}

A, $100 \%$ heated milk; $B, 75 \%$ heated milk $+25 \%$ raw milk; C, $50 \%$ heated milk $+50 \%$ raw milk; D, $25 \%$ heated milk $+75 \%$ raw milk; $E, 100 \%$ raw milk; means with different superscripts in the same raw differed highly significantly $(p<0.001)$

Highly significant $(p<0.001)$ difference was observed among the fat contents of milk prepared for different treatments (Table 1). The highest fat content was observed in the heated milk, followed by the sample with $75 \%$ heated milk. It was evident that as the proportion of boiled milk decreased, the fat content reduced. As a consequence, the lowest fat content was found in sample E ( $100 \%$ raw milk). According to USDA (1980), milk contains minimum 3.8\% fat. The values obtained in this experiment were higher than the minimum values mentioned by many researchers and standards. This might be due to high fat contents in milk collected from BAU Dairy farm, as was also observed by Mustafa (1997). Cow milk generally contains between 30 and $40 \mathrm{~g} / \mathrm{kg}$, although values as high as $55 \mathrm{~g} / \mathrm{kg}$ have been reported in raw milk (Fox 1995). Most milks consumed now contain a standardized fat content of around $35 \mathrm{~g} / \mathrm{kg}$. The increase in fat content in heated milk might be attributed to evaporation of moisture as a result of heat treatment, thus increasing the concentration of milk fat (Walstra and Jenness 1984).

The lowest protein content was observed in the heated milk, followed by the sample with $75 \%$ heated milk (Table 1). On the other hand, the highest protein content was found in treatment $\mathrm{E}$ ( $100 \%$ raw milk). It was evident that as the proportion of heated milk is decreased, the protein content increased. Adulteration by adding heated milk with raw milk decreases the protein percent in milk. Ostlie et al. (2003) reported that the average protein content of cow's milk was $35.2 \mathrm{~g} / \mathrm{kg}$. So, their results support the findings of present experiment. The concentration of protein in milk varies from $30-40 \mathrm{~g} / \mathrm{kg}$ (Goff, 2010). The percentage varies with the breed of the cow and in proportion to the amount of fat in the milk. There is a close relationship between the amount of fat and the amounts of protein in milk-the higher the fat, the higher the protein. The protein falls into two major groups: caseins $(80 \%)$ and whey proteins $(20 \%)$. The decrease in protein content in heated milk might be due to partial precipitation of whey protein as was coagulated when heated above $70^{\circ} \mathrm{C}$ (Walstra and Jenness 1984).

The ash contents of the milk varied significantly $(p<0.05)$ as presented in Table 1 . The highest value of ash obtained from treatment A (100\% Heated milk) and the lowest from treatment $E$ (100\% Raw milk). This result was similar to the results of I smail et al. (1974); who found the ash content of milk was $6.50 \pm 0.25 \mathrm{~g} / \mathrm{kg}$. The amount of ash content of cow milk was found to be 4.50 - $8.00 \mathrm{~g} / \mathrm{Kg}$ (Enb et al. 2009; Imran et al. 2008). However, Haenlein (1996) mentioned cow milk contains $6.5 \mathrm{~g} / \mathrm{Kg}$ ash. El-Shabrawy and Hagrass (1980) found that the ash content of raw, pasteurized and sterilized cow milk was $6.5 \mathrm{~g} / \mathrm{Kg}$, $7.8 \mathrm{~g} / \mathrm{kg}$ and $7.4 \mathrm{~g} / \mathrm{kg}$, respectively. It was revealed that ash content increased with heat treatment. All the findings of the current research falls within the range. 


\section{Turbidity index to detect mixing of heated and raw milk}

No significant difference was observed in $\mathrm{pH}$ values of milk (Table 1 ). Though relatively low $\mathrm{pH}$ value was found in treatment $\mathrm{A}$ ( $100 \%$ raw milk) all the samples showed $\mathrm{pH}$ values typical for cows milk. Mohamad et al. (1990) found that the $\mathrm{pH}$ value of raw, pasteurized and sterilized cow milk was $6.6,6.7$ and 6.68 respectively. Moreover, Walstra and Jenness (1984) reported that $\mathrm{pH}$ value of milk decreases as a result of heat treatment.

There were no significant differences among the acidity percentages of milk samples prepared from different treatments (Table 1 ). Slightly high acidity was found in the heated milk, followed by the sample with $75 \%$ heated milk. It was evident that as the proportion of boiled milk decreased, the percentage of acidity was also decreased. As a consequence, lower acidity content was found in raw milk sample. Generally acidity of normal milk samples are varies with in the range of 0.14 to $0.16 \%$, within an average of $0.15 \%$ (Eigel et al. 1984). However, Mohamad et al. (1990) found that the acidity percentage of raw, pasteurized and sterilized cow milk was $0.16,0.17$ and $0.18 \%$, respectively. Fresh milk shows an acidity of about $0.15 \%$ which is due to the presence of citrate, phosphate, carbon dioxide and milk casein. In this study, increase in acidity percentage of heated milk samples confirms the results of Walstra and Jenness (1984), who reported that acidity of milk increases as a result of heat treatment.

There was highly significant $(p<0.001)$ difference among the precipitate percentage of collected milk samples (Table 1 ). The highest precipitate percentage was observed in the raw milk, followed by the sample with $25 \%$ heated milk. It was evident that as the proportion of boiled milk increased, the percentage of precipitate reduced in the plasma. The amount of precipitate in milk plasma depends on the amount of uncoagulated whey proteins. If milk is previously heated above $70^{\circ} \mathrm{C}$ for a considerable time, almost all of the whey proteins (a-lactalbumin and $\beta$ lactoglobulin) coagulate. These coagulated proteins cannot gain entrance to plasma during filtration. As a consequence, the plasma gives a transparent appearance if heated at $100^{\circ} \mathrm{C}$ for 5 minutes. On the other hand, raw milk can pass its entire lot of whey proteins into plasma, thus gives turbid plasma upon heating. Mixed milks show a scenario in between, depending on the extent of heated milk that is mixed to the raw milk. When these heated plasma were filtered to collect the coagulated whey proteins (as depicted by the turbidity shown in Figure 1), the amount of proteins subsequently vary when expressed as percentage of the plasma.

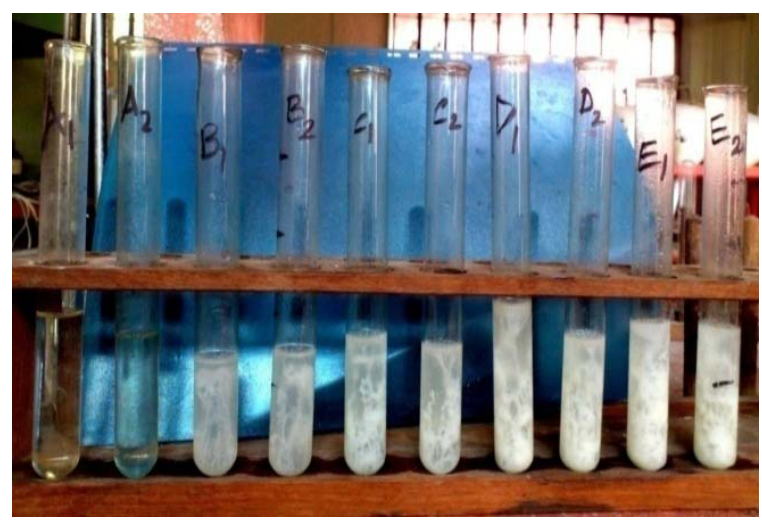

Figure 1. Extent of turbidity in plasma of different types of milk: $A 1 / A 2,100 \%$ heated milk; B1/B2, $75 \%$ heated milk+25\% raw milk; $\mathrm{C} 1 / \mathrm{C} 2,50 \%$ heated milk $+50 \%$ raw milk; D1/D2, 25\% heated milk+75\% raw milk; E1/E2, $100 \%$ raw milk

A positive correlation was found between precipitate and proportion of heated milk mixed with raw milk. As the amount of heated milk increased, the precipitate content also decreased, and vice versa. This correlation is significant at the $0.01 \%$ level (2-tailed). Moreover, a linear regression between precipitate percentage and proportion of heated milk mixed with raw milk was also found $\left(R^{2}=0.819\right.$; Figure 2$)$.

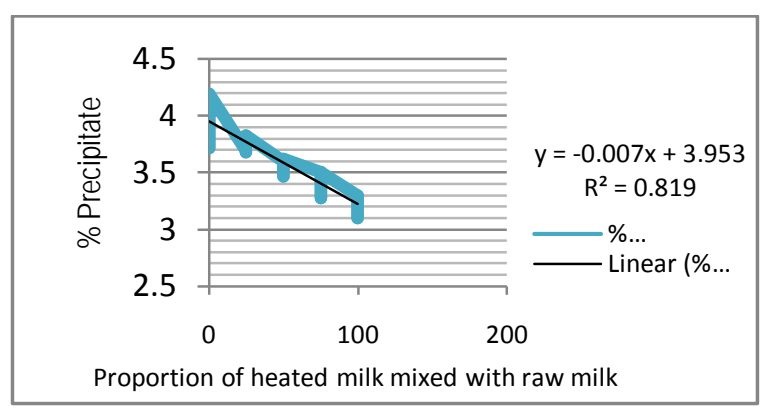

Figure 2. Correlation between precipitate $\%$ and proportion of heated milk mixed with raw milk 


\section{Conclusion}

From the results of the study it can be inferred that the developed turbidity index can successfully detect the percentage of heated milk added to raw milk. Turbidity index was developed based on the different amounts of precipitate formed as a result of mixing various predetermined portions of heated milk to raw milk in order to detect even the small amount $(\sim 25 \%)$ of heated milk mixed with raw milk. Chemical analyses revealed that there were a highly significant difference $(p<0.001)$ in case of precipitate presents in plasma as function to different levels of heated milk added. A strong correlation was also observed between precipitate and proportion of heated milk mixed with raw milk.

\section{References}

Aggarwala AC and Shamra RM (1961). A Laboratory Manual of Milk Inspection, $4^{\text {th }}$ edn. Asia Publishing House. Bombay, India.

AOAC (2003). Official Methods of Analysis. $17^{\text {th }}$ edn. Association of Official Agricultural Chemists. Washington DC, USA.

Clesceri LS, Greenberg AE, Eaton AD (1998). Standard Methods for the Examination of Water and Wastewater, 20 $0^{\text {th }}$ edn. American Public Health Association. Washington DC, USA.

Davies-Colley RJ, Smith DG (2001). Turbidity, suspended sediment, and water clarity: a review. Journal of the American Water Resources Association, 37: 1085-1101.

Eigel WN, Butler JE, Ernstrom CA, Farrell HM, Harwalkar VR, Jenness R, Whitney RM (1984). Nomenclature of proteins of cow's milk: fifth revision. Journal of Dairy Science, 67: 1599-1631.

El-Shabrawy SA, Hagrass AEA (1980). Some trace elements of buffalo's milk as determined by Atomic Absorption. Egyptian Journal of Dairy Science, 8: 103-107.

Enb A, Donia MAA, Abd-Rabou NS, AbouArab AAK, El-Senaity MH (2009). Chemical composition of raw milk and heavy metals behavior during processing of milk products. Global Veterinary, 3: 268-275.
Fox PF (1995). Advanced Dairy Chemistry: Volume 2. Lipids. $2^{\text {nd }}$ Edition. Chapman and Hall. New York, USA.

Goff HD (2010). Dairy Chemistry and Physics: Dairy Science and Technology.

Gomez AK and Gomez AA (1984) Statistical procedures for Agricultural Research. $2^{\text {nd }}$ Edition. John Wiley and Sons, New York, USA. P. 95-109.

Haenlein GFW (1996) Nutritional value of dairy products of ewes and goats milk. International Journal of Animal Science, 11: 395- 411.

Imran M, Khan H, Hassan SS, Khan R (2008). Physicochemical characteristics of various milk samples available in Pakistan. J. Zhejiang University Science, 9: 546-551.

Ismail AA, Aida A, Sirry I (1974). Behaviour of Cow's and Buffalo's cream in Butter Making. Egyptian J ournal of Dairy Science, 2: 75-82.

Mahboba IAA, Zubeir IEME (2007). The compositional quality of raw milk produced by some dairy cow's farms in Khartoum state, Sudan. Research Journal of Agriculture and Biological Science, 3: 902-906.

Mohamad KS, Mohamed FO, Al-Tamiemy SH (1990). Some chemical and physical characteristics of sterilized milk. Egyptian J ournal of Dairy Science, 18: 23-35.

Mustafa MD (1997). A study on the preparation of fruit dahi (yogurt). M.S. Thesis submitted to Department of Dairy Science, Bangladesh Agricultural University, Mymensingh. P. 2232.

Nelson JA, Trout GM (1948). Judging and grading milk, in Judging Dairy Products, $2^{\text {nd }}$ Edition. The Olsen Publishing Co. Wisconsin, USA. P. 70-71.

Ostlie HM, Helland MH, Narvhus JA (2003). Growth and metabolism of selected strains of probiotic bacteria in milk. International Journal of Food Microbiology. 87: 17-27.

USDA (United State Department of Agriculture) (1980). Federal and State Standards for the Composition of Milk Products, Agriculture Handbook, 51. US Government Printing Office. Washington DC, USA.

Walstra P, Jenness R (1984). Dairy Chemistry and Physics, John Wiley and Sons, Canada. P. 162-184. 